\title{
Nutritional value, bioactive compounds and antioxidant properties of three edible mushrooms from Poland
}

Sandrina A. Heleno ${ }^{\mathrm{a}, \mathrm{b}}$, Raíssa Carolina Ferreira ${ }^{\mathrm{c}}$, Amilcar L. Antonio ${ }^{\mathrm{a}}$, Maria-João R.P. Queiroz $^{\mathrm{b}}$, Lillian Barros ${ }^{\mathrm{a},}{ }^{,}$, Isabel C.F.R. Ferreira ${ }^{\mathrm{a} *}$

${ }^{a}$ Centro de Investigação de Montanha (CIMO), ESA, Instituto Politécnico de Bragança, Campus de Santa Apolónia, apartado 1172, 5301-854 Bragança, Portugal.

${ }^{\text {b} C e n t r o ~ d e ~ Q u i ́ m i c a, ~ U n i v e r s i d a d e ~ d o ~ M i n h o, ~ C a m p u s ~ d e ~ G u a l t a r ~ 4710-057 ~ B r a g a, ~}$ Portugal.

'IFSULDEMINAS, Campus Inconfidentes, Praça Tiradentes, 416, Inconfidentes-MG, Brasil

* Authors to whom correspondence should be addressed (Isabel C.F.R. Ferreira- e-mail: iferreira@ipb.pt; telephone +351-273-303219; fax +351-273-325405; Lillian Barros- email: lillian@ipb.pt; telephone +351-273-303309; fax +351-273-325405).

Running title: Valorization of edible mushrooms from Poland 


\begin{abstract}
Mushrooms contain a multitude of biomolecules with nutritional and/or biological activity. Among the bioactive molecules, phenolic compounds and tocopherols are the most responsible for their antioxidant activity. In the present work, Boletus edulis, Lentinus edodes and Xerocomus badius, three edible mushroom species originated from Poland, were analyzed for their chemical composition and antioxidant activity. Carbohydrates were the most abundant macronutrients, followed by proteins and ash. Fructose, mannitol and trehalose were the prevalent sugars, but glucose was only found in B. edulis. Polyunsaturated fatty acids predominated over mono and saturated fatty acids. Palmitic, oleic and linoleic acids were abundant in the three samples. $\alpha$ - and $\beta$ Tocopherols were quantified in all the samples, but $\gamma$-tocopherol was only identified in $X$. badius. Oxalic and fumaric acids were quantified in the three samples; quinic acid was only present in L. edodes, and malic and citric acids were only found in X. badius. $p$-Hydroxybenzoic, protocatechuic and cinnamic acids were quantified in all the species, while $p$-coumaric acid was only found in B. edulis. This species and X. badius revealed the highest antioxidant properties, being $B$. edulis more effective in radicals scavenging activity and reducing power, and $X$. badius in lipid peroxidation inhibition, which is related with the highest amounts in phenolic compounds and tocopherols, respectively.
\end{abstract}

\title{
KEYWORDS
}

Wild mushrooms; Nutritional value; Chemical composition; Antioxidant activity 


\section{Introduction}

Over the last decades, the consumption of mushrooms has significantly increased due to the scientific evidence of their ability to help the organism in the combat and prevention of several diseases (Ferreira, Barros, \& Abreu, 2009; Kalac, 2012). Fruiting bodies of mushrooms are consumed as a delicacy for their texture and flavor, but also for their nutritional properties that makes them even more attractable (Lindequist, Niedermeyer, \& Julich, 2005; Kalac, 2012). Mushrooms are also described as an excellent choice to include in low caloric diets since they have high amounts of dietary fiber, minerals, vitamins, water, protein, carbohydrates, and low content in lipids (Mattila et al., 2001; Heleno, Barros, Sousa, Martins, \& Ferreira, 2009; Kalac, 2012). Furthermore, mushrooms contain a huge variety of bioactive compounds, and proved to be effective mainly as antioxidants, anticancer and antimicrobial agents (Barros, Ferreira, \& Baptista, 2008; Ferreira, Vaz, Vasconcelos, \& Martins, 2010; Alves et al., 2012). Among the bioactive molecules, phenolic acids have attracted special attention since they are reported as strong antioxidants and the main responsible for the antioxidant properties of mushrooms (Ferreira et al., 2009; Palacios et al., 2011).

Lentinus edodes (Berk.) Pegler and Boletus edulis Bull. are two of the most consumed and popular mushrooms worldwide; being L. edodes the second most cultivated mushroom (Chang \& Miles, 2004) and B. edulis considered as the tastiest one among the Boletus genus (Jaworska \& Bernas, 2009). Several authors described these two mushroom species as being rich in nutrients and bioactive molecules, such as phenolic acids and tocopherols, that are related with their antioxidant activity (Cheung, Cheung, \& Ooi, 2003; Cheung \& Cheung, 2005; Heleno et al., 2011; Özyürek, Bener, Güçlü, \& Apak, 2014). Xerocomus badius is one of the most consumed mushroom in Poland. 
In the present work, the chemical composition of the mentioned mushroom species $(L$. edodes, B. edulis and X. badius), originated from Poland, was evaluated. Furthermore, the chemical compounds found in each sample were related with their antioxidant properties, measured as free radical scavenging activity, reducing power and lipid peroxidation inhibition.

\section{Materials and methods}

\subsection{Samples}

Commercial samples of Boletus edulis Bull., Lentinus edodes (Berk.) Pegler and Xerocomus badius (Fr.) E.-J.Gilbert, three edible dried mushrooms, were obtained in a local market in Poland, in November 2012. The specimens were kept at $-20{ }^{\circ} \mathrm{C}$ until further analysis.

\subsection{Standards and Reagents}

Acetonitrile $99.9 \%$, n-hexane $95 \%$ and ethyl acetate $99.8 \%$ were of HPLC grade from Fisher Scientific (Lisbon, Portugal). The fatty acids methyl ester (FAME) reference standard mixture 37 (standard 47885-U) was purchased from Sigma (St. Louis, MO, USA), as also other individual fatty acid isomers and standards of sugars (L-(+)arabinose, D-(+)-mannitol, D-(+)-trehalose), tocopherols ( $\alpha-, \beta-$, and $\gamma$-isoforms), organic acids (malic, oxalic quinic, citric and fumaric acids), phenolic compounds ( $p$ hydroxybenzoic, protocatechuic, $p$-coumaric and cinnamic acids), trolox (6-hydroxy2,5,7,8-tetramethylchroman-2-carboxylic acid). Racemic tocol, $50 \mathrm{mg} / \mathrm{mL}$, was purchased from Matreya (PA, USA). 2,2-Diphenyl-1-picrylhydrazyl (DPPH) was obtained from Alfa Aesar (Ward Hill, MA, USA). Water was treated in a Milli-Q water purification system (TGI Pure Water Systems, Greenville, SC, USA). 


\subsection{Chemical composition}

\subsubsection{Nutritional value}

The samples were analysed for chemical composition (moisture, proteins, fat, carbohydrates and ash) using the AOAC procedures (AOAC, 1995). The crude protein content $(\mathrm{N} \times 4.38)$ of the samples was estimated by the macro-Kjeldahl method; the crude fat was determined by extracting a known weight of powdered sample with petroleum ether, using a Soxhlet apparatus; the ash content was determined by incineration at $600 \pm 15{ }^{\circ} \mathrm{C}$. Total carbohydrates were calculated by difference. Energy was calculated according to the following equation: Energy $(\mathrm{kcal})=4 \times(\mathrm{g}$ protein $+\mathrm{g}$ carbohydrate $)+9 \times(\mathrm{g}$ fat $)$.

\subsubsection{Free sugars}

Free sugars were determined by a High Performance Liquid Chromatography (HPLC) system consisted of an integrated system with a pump (Knauer, Smartline system 1000, Berlin, Germany), degasser system (Smartline manager 5000) and auto-sampler (AS2057 Jasco, Easton, MD, USA), coupled to a refraction index detector (RI detector Knauer Smartline 2300) as previously described by the authors (Heleno et al., 2009). Sugars were identified by comparing the relative retention times of sample peaks with standards. Data were analysed using Clarity 2.4 Software (DataApex, Prague, Czech Republic). The chromatographic separation was achieved with a Eurospher 100-5 $\mathrm{NH}_{2}$ column $\left(5 \mu \mathrm{m}, 250 \mathrm{~mm} \times 4.6 \mathrm{~mm}\right.$ i.d., Knauer) operating at $35^{\circ} \mathrm{C}(7971 \mathrm{R}$ Grace oven $)$. The mobile phase was acetonitrile/deionized water, 70:30 $(v / v)$ at a flow rate of 1 $\mathrm{mL} / \mathrm{min}$. Quantification was based on the RI signal response of each standard, using the internal standard (IS, raffinose) method and by using calibration curves obtained from commercial standards of each compound. The results were expressed in g per $100 \mathrm{~g}$ of dry weight. 


\subsubsection{Fatty acids}

Fatty acids were determined after a trans-esterification procedure as described previously by the authors (Heleno et al., 2009), using a gas chromatographer (DANI 1000, Contone, Switzerland) equipped with a split/splitless injector and a flame ionization detector (GC-FID at $260{ }^{\circ} \mathrm{C}$ ) and a Macherey-Nagel (Düren, Germany) column (50\% cyanopropyl-methyl-50\% phenylmethylpolysiloxane, $30 \mathrm{~m} \times 0.32 \mathrm{~mm}$ i.d. $\times 0.25 \mu \mathrm{m} \mathrm{d}_{\mathrm{f}}$ ). The oven temperature program was as follows: the initial temperature of the column was $50{ }^{\circ} \mathrm{C}$, held for $2 \mathrm{~min}$, then a $30{ }^{\circ} \mathrm{C} / \mathrm{min}$ ramp to $125{ }^{\circ} \mathrm{C}, 5{ }^{\circ} \mathrm{C} / \mathrm{min}$ ramp to $160{ }^{\circ} \mathrm{C}, 20{ }^{\circ} \mathrm{C} / \mathrm{min}$ ramp to $180{ }^{\circ} \mathrm{C}, 3{ }^{\circ} \mathrm{C} / \mathrm{min}$ ramp to $200{ }^{\circ} \mathrm{C}, 20{ }^{\circ} \mathrm{C} / \mathrm{min} \mathrm{ramp}$ to $220^{\circ} \mathrm{C}$ and held for $15 \mathrm{~min}$. The carrier gas (hydrogen) flow-rate was $4.0 \mathrm{~mL} / \mathrm{min}$ (0.61 bar), measured at $50^{\circ} \mathrm{C}$. Split injection $(1: 40)$ was carried out at $250{ }^{\circ} \mathrm{C}$. Fatty acid identification was made by comparing the relative retention times of FAME peaks from samples with standards. The results were recorded and processed using CSW 1.7 software (DataApex 1.7, Prague, Czech Republic). The results were expressed in relative percentage of each fatty acid.

\subsubsection{Tocopherols}

Tocopherols were determined following a procedure previously described by the authors (Heleno, Barros, Sousa, Martins, \& Ferreira, 2010). Analysis was performed by HPLC (equipment described above), and a fluorescence detector (FP-2020; Jasco, Easton, MD, USA) programmed for excitation at $290 \mathrm{~nm}$ and emission at $330 \mathrm{~nm}$. The chromatographic separation was achieved with a Polyamide II normal-phase column (5 $\mu \mathrm{m}, 250 \mathrm{~mm} \times 4.6 \mathrm{~mm}$ i.d., YMC Waters), operating at $35^{\circ} \mathrm{C}$. The mobile phase used was a mixture of n-hexane and ethyl acetate $(70: 30, v / v)$ at a flow rate of $1 \mathrm{~mL} / \mathrm{min}$. The compounds were identified by chromatographic comparisons with authentic standards. 
Quantification was based on the fluorescence signal response of each standard, using the IS (tocol) method and by using calibration curves obtained from commercial standards of each compound. The results were expressed in $\mu \mathrm{g}$ per $100 \mathrm{~g}$ of dry weight.

\subsubsection{Organic acids}

Organic acids were determined following a procedure previously described by the authors (Reis et al., 2013). Analysis was performed by ultra-fast liquid chromatograph (UFLC) coupled to photodiode array detector (PDA), using a Shimadzu 20A series UFLC (Shimadzu Corporation, Kyoto, Japan). Separation was achieved on a SphereClone (Phenomenex) reverse phase $\mathrm{C}_{18}$ column $(5 \mu \mathrm{m}, 250 \mathrm{~mm} \times 4.6 \mathrm{~mm}$ i.d.) thermostatted at $35^{\circ} \mathrm{C}$. The elution was performed with sulphuric acid $3.6 \mathrm{mM}$ using a flow rate of $0.8 \mathrm{~mL} / \mathrm{min}$. Detection was carried out in a PDA, using $215 \mathrm{~nm}$ and 245 as preferred wavelengths. The organic acids were quantified by comparison of the area of their peaks recorded at $215 \mathrm{~nm}$ with calibration curves obtained from commercial standards of each compound. The results were expressed in g per $100 \mathrm{~g}$ of dry weight.

\subsubsection{Phenolic compounds}

Phenolic acids determination was performed using a Shimadzu 20A series ultra-fast liquid chromatograph (UFLC, Shimadzu, equipment described above) as previously described by Reis et al. (2013). Separation was achieved on an Aqua (3 $\mu \mathrm{m}, 150 \mathrm{~mm} x$ $4.6 \mathrm{~mm}$ i.d., Phenomenex, Torrance, CA, USA) reverse phase $\mathrm{C}_{18}$ column $(5 \mu \mathrm{m}, 250$ $\mathrm{mm} \times 4.6 \mathrm{~mm}$ i.d.) thermostatted at $35^{\circ} \mathrm{C}$. The mobile phase was: (A) $0.1 \%$ formic acid in water, (B) 100\% HPLC-grade acetonitrile. The elution gradient established was 10\% $\mathrm{A}$ to $15 \% \mathrm{~B}$ over $5 \mathrm{~min}, 15-25 \% \mathrm{~A}$ in $\mathrm{B}$ over $5 \mathrm{~min}, 25-35 \% \mathrm{~A}$ in $\mathrm{B}$ over $10 \mathrm{~min}$, isocratic $50 \% \mathrm{~B}$ for $10 \mathrm{~min}$, and re-equilibration of the column, using a flow rate of 
$0.5 \mathrm{ml} / \mathrm{min}$. Detection was carried out in a photodiode array detector (PDA), using 280 $\mathrm{nm}$ as the preferred wavelength. The phenolic compounds were quantified by comparison of the area of their peaks recorded at $280 \mathrm{~nm}$ with calibration curves obtained from commercial standards of each compound. The results were expressed in mg per $100 \mathrm{~g}$ of dry weight.

\subsection{Antioxidant activity}

\subsubsection{Extracts preparation}

The lyophilized powder $(1.5 \mathrm{~g})$ was extracted by stirring with $40 \mathrm{~mL}$ of methanol $\left(25^{\circ} \mathrm{C}\right.$ at $150 \mathrm{rpm}$ ) for $2 \mathrm{~h}$ and subsequently filtered through Whatman No. 4 paper.

The residue was then extracted with $20 \mathrm{~mL}$ of methanol $\left(25^{\circ} \mathrm{C}\right.$ at $\left.150 \mathrm{rpm}\right)$ for $2 \mathrm{~h}$. The combined methanolic extracts were evaporated at $40^{\circ} \mathrm{C}$ (rotary evaporator Büchi R-210) to dryness redissolved in methanol at a concentration of $50 \mathrm{mg} / \mathrm{mL}$, and stored at $4{ }^{\circ} \mathrm{C}$ until analysis (Reis et al., 2011).

\subsubsection{General}

Successive dilutions of the stock solution of the phenolic extracts were made and submitted to in vitro assays already described by the authors (Heleno et al., 2009) to evaluate the antioxidant activity of the samples. The sample concentrations providing $50 \%$ of antioxidant activity $\left(\mathrm{EC}_{50}\right)$ or 0.5 of absorbance $\left(\mathrm{EC}_{0.5}\right)$ were calculated from the graphs of antioxidant activity percentages (DPPH, $\beta$-carotene/linoleate and TBARS assays) or absorbance at $690 \mathrm{~nm}$ (reducing power assay) against sample concentrations. In the Folin-Ciocalteu assay (for determination of total phenolics), the results were expressed as mg of gallic acid equivalents (GAE) per $\mathrm{g}$ of extract. The commercial standard trolox was used as positive control. 


\subsubsection{Total phenolics by Folin-Ciocalteu assay}

The extract solution $(1 \mathrm{~mL})$ was mixed with Folin-Ciocalteu reagent $(5 \mathrm{~mL}$, previously diluted with water $1: 10, \mathrm{v} / \mathrm{v})$ and sodium carbonate $(75 \mathrm{~g} / \mathrm{L}, 4 \mathrm{~mL})$. The tubes were vortex mixed for $15 \mathrm{~s}$ and allowed to stand for $30 \mathrm{~min}$ at $40^{\circ} \mathrm{C}$ for colour development. Absorbance was then measured at $765 \mathrm{~nm}$.

\subsubsection{Reducing power by Ferricyanide/Prussian blue assay}

The assay was performed using a Microplate Reader ELX800 Microplate Reader (BioTek Instruments, Inc., Winooski, VT, USA). The different concentrations of the extracts $(0.5 \mathrm{~mL})$ were mixed with sodium phosphate buffer $(200 \mathrm{mmol} / \mathrm{L}, \mathrm{pH} 6.6,0.5 \mathrm{~mL})$ and potassium ferricyanide $(1 \% \mathrm{w} / \mathrm{v}, 0.5 \mathrm{~mL})$. For each concentration, the mixture was incubated at $50{ }^{\circ} \mathrm{C}$ for $20 \mathrm{~min}$, and trichloroacetic acid $(10 \% \mathrm{w} / \mathrm{v}, 0.5 \mathrm{~mL})$ was added. The mixture $(0.8 \mathrm{~mL})$ was poured in the 48 -wells, as also deionized water $(0.8 \mathrm{~mL})$ and ferric chloride $(0.1 \% \mathrm{w} / \mathrm{v}, 0.16 \mathrm{~mL})$, and the absorbance was measured at $690 \mathrm{~nm}$.

\subsubsection{Scavenging activity by DPPH assay}

This methodology was performed using the Microplate Reader mentioned above. The reaction mixture on 96 wells plate consisted of a solution by well of the extract solutions with different concentrations $(30 \mu \mathrm{L})$ and methanolic solution $(270 \mu \mathrm{L})$ containing DPPH radicals $\left(6 \times 10^{-5} \mathrm{~mol} / \mathrm{L}\right)$. The mixture was left to stand for $30 \mathrm{~min}$ in the dark, and the absorption was measured at $515 \mathrm{~nm}$. The radical scavenging activity (RSA) was calculated as a percentage of DPPH discolouration using the equation: \% $R S A=\left[\left(A_{D P P H}-A_{S}\right) / A_{D P P H}\right] \times 100$, where $A_{S}$ is the absorbance of the solution containing the sample and $\mathrm{A}_{\mathrm{DPPH}}$ is the absorbance of the DPPH solution. 


\subsubsection{Lipid peroxidation inhibition by $\beta$-carotene/linoleate and TBARS assays}

The first methodology was $\beta$-carotene/linoleate assay: A solution of $\beta$-carotene was prepared by dissolving $\beta$-carotene $(2 \mathrm{mg})$ in chloroform $(10 \mathrm{~mL})$. Two millilitres of this solution were pipetted into a round-bottom flask. The chloroform was removed at $40{ }^{\circ} \mathrm{C}$ under vacuum and linoleic acid (40 mg), Tween 80 emulsifier (400 mg), and distilled water $(100 \mathrm{~mL})$ were added to the flask with vigorous shaking. Aliquots $(4.8 \mathrm{~mL})$ of this emulsion were transferred into test tubes containing extract solutions with different concentrations $(0.2 \mathrm{~mL})$. The tubes were shaken and incubated at $50{ }^{\circ} \mathrm{C}$ in a water bath. As soon as the emulsion was added to each tube, the zero time absorbance was measured at $470 \mathrm{~nm}$. $\beta$-Carotene bleaching inhibition was calculated using the following equation: ( $\beta$-carotene content after $2 \mathrm{~h}$ of assay/initial $\beta$-carotene content) $\times$ 100. The second methodology was TBARS (thiobarbituric acid reactive species) assay: Porcine brains were obtained from official slaughtering animals, dissected, and homogenized with a Polytron in ice cold Tris-HCl buffer $(20 \mathrm{mM}, \mathrm{pH} 7.4)$ to produce a $1: 2 \mathrm{w} / \mathrm{v}$ brain tissue homogenate which was centrifuged at $3000 \mathrm{~g}$ for10 min. An aliquot $(100 \mu \mathrm{L})$ of the supernatant was incubated with the different concentrations of the samples solutions $(200 \mu \mathrm{L})$ in the presence of $\mathrm{FeSO}_{4}(10 \mathrm{mM} ; 100 \mu \mathrm{L})$ and ascorbic acid $(0.1 \mathrm{mM} ; 100 \mu \mathrm{L})$ at $37^{\circ} \mathrm{C}$ for $1 \mathrm{~h}$. The reaction was stopped by the addition of trichloroacetic acid $(28 \% \mathrm{w} / \mathrm{v}, 500 \mu \mathrm{L})$, followed by thiobarbituric acid (TBA, $2 \%$, w/v, $380 \mu \mathrm{L}$ ), and the mixture was then heated at $80{ }^{\circ} \mathrm{C}$ for $20 \mathrm{~min}$. After centrifugation at $3000 \mathrm{~g}$ for $10 \mathrm{~min}$ to remove the precipitated protein, the colour intensity of the malondialdehyde (MDA)-TBA complex in the supernatant was measured by its absorbance at $532 \mathrm{~nm}$. The inhibition ratio (\%) was calculated using the following 
formula: Inhibition ratio $(\%)=[(\mathrm{A}-\mathrm{B}) / \mathrm{A}] \times 100 \%$, where $\mathrm{A}$ and $\mathrm{B}$ were the absorbance of the control and the sample solution, respectively.

\subsection{Statistical analysis}

Three specimens of each mushroom species were used, and all the assays were carried out in triplicate. The results were expressed as mean values and standard deviation (SD), and further analyzed using one-way analysis of variance (ANOVA) followed by Tukey's HSD Test with $\alpha=0.05$. This treatment was carried out using SPSS v. 22.0 program (IBM Corp., USA).

\section{Results and discussion}

\subsection{Chemical composition}

The results concerning the nutritional value, free sugars and fatty acids composition are presented in Table 1. Carbohydrates were the major constituents, followed by proteins and ash. Fat contents were low, being higher in X. badius and lower in L. edodes. The energetic contribution of $B$. edulis and $X$. badius were higher and very similar, due to the higher contribution of carbohydrates and fat. For $B$. edulis these values are in agreement with previous works reporting the nutritional values of $B$. edulis from Portugal (Heleno et al., 2011; Fernandes et al., 2013); nevertheless, the values presented herein are slightly different, with higher contents in carbohydrates and lower contents in proteins. Other authors reported the nutritional value of cultivated L. edodes, particularly lower ash, carbohydrates, proteins and fat contents (Manzi, Gambelli, Marconi, Vivanti, \& Pizzoferrato, 1999; Çaglarirmak, 2007; Reis, Barros, Martins, \& Ferreira, 2012). 
Fructose, mannitol and trehalose were found in the three samples, while glucose was only found in B. edulis (Table 1). L. edodes showed the highest content in total sugars and in fructose, while $X$. badius gave the highest content in mannitol, and B. edulis the highest content in trehalose. Trehalose predominated in B. edulis and L. edodes, followed by mannitol; otherwise, in $X$. badius, mannitol was the predominant free sugar, followed by trehalose. Heleno et al. (2011) and Fernandes et al. (2013) also reported trehalose as the most abundant sugar in $B$. edulis followed by mannitol. Reis et al. (2012) reported mannitol as the prevalent sugar, followed by trehalose in L. edodes; herein, the contrary was observed.

Regarding the fatty acids composition (Table 1), palmitic acid (C16:0), stearic acid (C18:0), oleic acid (C18:1n9c), linoleic acid (C18:2n6c) and $\alpha$-linolenic acid (C18:3n3) were the fatty acids present in major percentages. Polyunsaturated fatty acids (PUFA) predominated over saturated fatty acids (SFA) and monounsaturated fatty acids (MUFA) in all the mushroom species, due to the high contribution of linoleic acid. $L$. edodes present a considerable amount of linoleic acid in comparison with B. edulis and $X$. badius, but a much lower content in oleic acid.

These values are in agreement with the ones reported by other authors for B. edulis (Heleno et al., 2011; Fernandes et al., 2013) and L. edodes (Reis et al., 2012). Nevertheless, Heleno et al. (2011) reported a higher content in oleic acid leading to a predominance of MUFA over SFA and PUFA. About 18 less abundant fatty acids were also identified and quantified in the samples.

As far as we know, there is only one report on fatty acids composition of the sporocarps of X. badius (Karlinski, Ravnskov, Kieliszewska-Rokicka, \& Larsen, 2007).

Concerning the tocopherols (Table 2), $\alpha$ and $\beta$ isoforms were found in B. edulis and $L$. edodes, while $\gamma$ - isoform was only found in $X$. badius. This latter revealed the highest 
content in total tocopherols due the much higher amounts in all the presented isoforms. $\gamma$ - and $\delta$-Tocopherols were not found in B. edulis in this study, nevertheless in other reports of Portuguese B. edulis, these two isoforms were identified (Heleno et al., 2011; Fernandes et al., 2013), as well as in another study with B. edulis from Gorj country (Vamanu \& Nita, 2013). Moreover, in the present study, $\beta$-tocopherol was identified and was the most predominant isoform, while in other reports this isoform did not appeared. L. edodes also presented the isoforms in different amounts; in the present study only $\alpha$ and $\beta$ isoforms were identified, while Reis et al. (2012) reported the presence of $\alpha, \gamma$ - and $\delta$-tocopherols and the absence of $\beta$-tocopherol. As far as we know there are no reports in literature describing the nutritional value of $X$. badius.

Among the organic acids (Table 2), oxalic, quinic, malic, citric and fumaric acids were identified depending on the sample. Oxalic and fumaric acids were found in all the species; quinic acid was only found in L. edodes, and malic and citric acids were only identified in $X$. badius. This latter revealed the highest organic acids content due to the presence of malic and citric acids. Fernandes et al. (2013) reported the presence of citric acid in Portuguese B. edulis; nevertheless, the amounts of oxalic and fumaric acids were very similar to the ones obtained in the present study.

Regarding phenolic compounds (Table 2), protocatechuic, $p$-hydroxybenzoic, $p$ coumaric and cinnamic acids were identified and quantified depending on the mushroom species. Protocatechuic, $p$-hydroxybenzoic and cinnamic acids were found in all the three samples, while $p$-coumaric acid was only found in B. edulis contributing to the highest amount in total phenolic compounds presented by this latter, as well as the highest content in $p$-hydroxybenzoic acid. These values are in agreement with the ones reported in previous studies on Portuguese samples of B. edulis and L. edodes (Heleno et al., 2011; Reis, Martins, Barros, \& Ferreira, 2012a). Nevertheless, Vamanu \& Nita 
(2013) reported the presence of rosmarinic acid in B. edulis from Gorj contry. Palacios et al. (2011) described the phenolic composition of B. edulis from Spain and reported the presence of caffeic, chlorogenic, gallic, gentisic and homogentisic acids as well as higher contents in protocatechuic and $p$-hydroxybenzoic acids, but lower contents in $p$ coumaric acid.

The differences observed in the chemical composition can be due to various factors. In the case of $B$. edulis, the studied species is originated from Poland whereas the other authors reported the chemical composition of B. edulis originated from Portugal. Thus, the differences observed in the chemical composition when comparing with Heleno et al. (2011) and Fernandes et al. (2013), may be due to the different environmental conditions, such as temperature and relative humidity, involved in mushrooms maturation stages that can affect their secondary metabolism and consequently the quantity and variety of secondary metabolites production. Regarding L. edodes, the species analyzed by Reis et al. (2012) was a commercial sample that could suffer industrial processes. The storage conditions and also the composition of the growing subtract can directly influence the chemical constituents of the produced mushrooms (Stojkovic et al., 2014).

\subsection{Antioxidant activity}

The antioxidant activity was assessed by four different assays measuring reducing power, free radicals scavenging activity, $\beta$-carotene bleaching inhibition and lipid peroxidation inhibition (Figures 1). B. edulis and $X$. badius revealed the highest antioxidant properties, presenting the lowest $\mathrm{EC}_{50}$ values. $B$. edulis showed the highest scavenging activity and reducing power, which could be related to its higher content in total phenolics (Figure 2), higher concentration of $p$-hydroxybenzoic acid, and also the 
presence of $p$-coumaric acid, and the highest amount in total phenolic compounds; in fact, these molecules are known for being strong free radical scavengers and metal chelators.

$X$. badius showed the highest lipid peroxidation inhibition, evaluated by $\beta$ carotene/linoleate and TBARS assays. This could be related with its highest content in total tocopherols, since these molecules participate in reactions occurring in lipidic environment.

L. edodes revealed the lowest activity presenting the lowest amount in total phenolic compounds and total tocopherols.

The studied sample of $B$. edulis revealed higher $\mathrm{EC}_{50}$ values for DPPH assay (1.80 $\mathrm{mg} / \mathrm{mL}$ ) than B. edulis samples from Portugal (Heleno et al., 2011; Fernandes et al., 2013) $\left(0.43\right.$ and $1.54 \mathrm{mg} / \mathrm{mL}$, respectively), but lower $\mathrm{EC}_{50}$ values in the reducing power assay: ferricianide Prussian/blue assay (1.16 and $0.71 \mathrm{mg} / \mathrm{mL}$ ). Moreover, Palacios et al. (2011) reported lower $\mathrm{EC}_{50}$ values in the DPPH scavenging activity and reducing power (0.73 and $0.34 \mathrm{mg} / \mathrm{mL}$, respectively). Regarding lipid peroxidation inhibition, the $\mathrm{EC}_{50}$ values were similar to the ones obtained by Fernandes et al. (2013), but lower than the ones reported by Heleno et al. (2011) for the $\beta$-carotene/linoleate assay $(2.46 \mathrm{mg} / \mathrm{mL})$.

Cultivated L. edodes originated from Portugal was also previously studied for its antioxidant activity using the same antioxidant assays and the values obtained were very similar to the ones reported herein, with the exception of TBARS assay that revealed lower $\mathrm{EC}_{50}$ value $(1.64 \mathrm{mg} / \mathrm{mL})$ (Reis et al., 2012a). 


\section{CONCLUSION}

B. edulis, L. edodes and X. badius proved to be rich sources of carbohydrates, free sugars and proteins, containing also different bioactive compounds such as organic acids, phenolic compounds and tocopherols. Polyunsaturated fatty acids predominated over mono and unsaturated fatty acids. The studied mushroom species are poor in fat content, making them low caloric foods. Furthermore, all these samples revealed antioxidant activity, being B. edulis more effective in DPPH and reducing power assays, which is related with the highest amount in total phenolic compounds, while $X$. badius was more effective in lipid peroxidation inhibition assays, due to the higher content in total tocopherols. As far as we know this is the first report describing the chemical composition and antioxidant activity of B. edulis, L. edodes and X. badius originated from Poland.

\section{ACKNOWLEDGMENTS}

The authors are grateful to Fundação para a Ciência e a Tecnologia (FCT, Portugal) for financial support to CIMO (strategic project PEst-OE/AGR/UI0690/2011), S.A. Heleno grant (BD/70304/2010).

\section{REFERENCES}

Alves, M. J., Ferreira, I. C. F. R., Dias, J., Teixeira, V., Martins, A., Pintado, M. (2012). A review on antimicrobial activity of mushroom (Basidiomycetes) extracts and isolated compounds. Planta Medica, 78, 1707-1718.

AOAC (1995). Official methods of analysis (16th Ed.). Arlington VA, USA: Association of Official Analytical Chemists. 
Barros, L., Ferreira, I. C. F. R., Baptista , P. (2008). Phenolics and antioxidant activity of the mushroom Leucopaxillus giganteus mycelium at different carbon sources. Food Science and Technology International, 14, 47-55.

Çaglarirmak, N. (2007). The nutrients of exotic mushrooms (Lentinula edodes and Pleurotus species) and an estimated approach to the volatile compounds. Food Chemistry, 105, 1188-1194.

Chang, S. T., Miles, P. G. (2004). Mushrooms: Cultivation, Nutritional Value, Medicinal Effect, and Environmental Impact, $2^{\text {nd }}$ ed.; Boca Raton, FL, USA: CRC Press.

Cheung, L. M., Cheung, P. C. K., Ooi, V. E. C. (2003). Antioxidant activity and total phenolics of edible mushroom extracts. Food Chemistry, 81, 249-255.

Cheung, L. M., Cheung, P. C. K. (2005). Mushroom extracts with antioxidant activity against lipid peroxidation. Food Chemistry, 89, 403-409.

Fernandes, A., Barreira, J. C. M., António, A. L., Santos, P. M. P., Martins, A., Oliveira, M. B. P. P., Ferreira, I. C. F R. (2013). Study of chemical changes and antioxidant activity variation induced by gamma-irradiation on wild mushrooms: Comparative study through principal component analysis. Food Research International, 54, 18-25.

Ferreira, I. C. F. R, Barros, L., Abreu, R. M. V. (2009). Antioxidants in Wild mushrooms. Current Medicinal Chemistry, 16,1543-1560.

Ferreira, I. C. F. R, Vaz, J. A., Vasconcelos, M. H., Martins, A. (2010). Compounds from Wild Mushrooms with Antitumor Potential. Anticancer Agents in Medicinal Chemistry, 10, 424-436.

Finimundy, T. C., Gambato, G., Fontana, R., Camassola, M., Salvador, M., Moura, S., Hess, J., Henriques, J. A. P., Dillon, A. J. P., Roesch-Ely, M. (2013). Aqueous 
extracts of Lentinula edodes and Pleurotus sajor-caju exhibit high antioxidant capability and promising in vitro antitumor activity. Nutrition Research, 33, 7684.

Heleno, S. A., Barros, L., Sousa, M. J., Martins, A., Ferreira, I. C. F. R. (2009). Study and characterization of selected nutrients in wild mushrooms from Portugal by gas chromatography and high performance liquid chromatography. Microchemical Journal, 93, 195-199.

Heleno, S. A., Barros, L., Sousa, M. J., Martins, A., Buelga, C. S., Ferreira, I. C. F. R. (2011). Targeted metabolites analysis in wild Boletus species. LWT-Food Science and Technology, 44, 1343-1348.

Heleno, S. A., Barros, L., Sousa, M. J., Martins, A., Ferreira, I. C. F. R. (2010). Tocopherols composition of Portuguese wild mushrooms with antioxidant capacity. Food Chemistry, 119, 1443-1450.

Jaworska, G. , Bernas, E. (2009). The effect of preliminary processing and period of storage on the quality of frozen Boletus edulis (Bull: Fr.) mushrooms. Food Chemistry, 113, 936-943.

Kalac, P. (2012). Chemical composition and nutritional value of European species of wild growing mushrooms, In Mushrooms: types, properties and nutrition. Editors: S. Andres and N. Baumann. Nova Science Publishers, 130-151.

Karlinski, L., Ravnskov, S., Kieliszewska-Rokicka, B., Larsen J. (2007). Fatty acid composition of various ectomycorrhizal fungi and ectomycorrhizas of Norway spruce. Soil Biology and Biochemistry, 39, 854-866.

Lindequist, U., Niedermeyer, T. H. J., Julich, W. D. (2005). The pharmacological potential of mushrooms. Evidence-Based Complementary and Alternative Medicine, 2, 285-299. 
Manzi, P., Gambelli, L., Marconi, S., Vivanti, V., Pizzoferrato, L. (1999). Nutrients in edible mushrooms: an interspecies comparative study. Food Chemistry, 65, 477482.

Mattila, P., Konko, K., Eurola, M., Pihlava, J. M., Astola, J., Vahteristo, L., Hietaniemi, V., Kumpulainen, J., Valtonen, M., Piironen, V. (2001). Contents of vitamins, mineral elements, and some phenolic compounds in cultivated mushrooms. Journal of Agricultural and Food Chemistry, 49, 2343-2348.

Özyürek, M., Bener, M., Güçlü. K., Apak, R. (2014). Antioxidant/antiradical properties of microwave-assisted extracts of three wild edible mushrooms. Food Chemistry, $157,323-331$.

Palacios, I., Lozano, M., Moro, C., D’Arrigo, M., Rostagno, M. A., Martínez, J. A., García-Lafuente, A., Guillamón, E., Villares, A. (2011). Antioxidant properties of phenolic compounds occurring in edible mushrooms. Food Chemistry, 128, 674678.

Reis, F. S., Martins, A., Barros, L., Ferreira, I. C. F. R. (2012a). Antioxidant properties and phenolic profile of the most widely appreciated cultivated mushrooms: A comparative study between in vivo and in vitro samples. Food and Chemical Toxicology, 50, 1201-1207.

Reis, F. S., Barros, L., Martins, A., Ferreira, I. C. F. R. (2012). Chemical composition and nutritional value of the most widely appreciated cultivated mushrooms: An inter-species comparative study. Food Chemical and Toxicology, 50, 191-197.

Reis, F. S., Barros, L., Calhelha, R. C., Cirić, A., van Griensven, L. J., Soković, M., Ferreira, I. C. F. R. (2013). The methanolic extract of Cordyceps militaris (L.) Link fruiting body shows antioxidant, antibacterial, antifungal and antihuman tumor cell lines properties. Food Chemical and Toxicology, 62, 91-98. 
Reis, F. S., Heleno, S. A., Barros, L., Sousa, M. J., Martins, M., Santos-Buelga, C., Ferreira, I. C. F. R. (2011). Toward the Antioxidant and Chemical Characterization of Mycorrhizal Mushrooms from Northeast Portugal. Journal of Food Science, 76, 824-830.

Stojkovic, D., Reis, F., Glamoclija, J., Ciric, A., Barros, L., Van Griensven, L.J.L.D., Ferreira, I.C.F.R., Sokovic, M. (2014). Cultivated strains of Agaricus bisporus and A. brasiliensis: chemical characterization and evaluation of antioxidant and antimicrobial properties for the final healthy product - natural preservatives in yoghurt. Food and Function, 5, 1602-1612.

Vamanu, E., Nita, S. (2013). Antioxidant Capacity and the Correlation with Major Phenolic Compounds, Anthocyanin, and Tocopherol Content in Various Extracts from the Wild Edible Boletus edulis Mushroom. Biomed Research International, $2013,11$. 
Table 1. Proximate composition, free sugars and fatty acids identified in Boletus edulis, Lentinus edodes and Xerocomus badius fruiting bodies from Poland.

\begin{tabular}{llll}
\hline Parameter & Boletus edulis & Lentinus edodes & Xerocomus badius \\
\hline Ash $(\mathrm{g} / 100 \mathrm{~g} \mathrm{dw})$ & $5.26 \pm 0.44^{\mathrm{c}}$ & $6.24 \pm 0.05^{\mathrm{b}}$ & $7.32 \pm 0.02^{\mathrm{a}}$ \\
Carbohydrates & $81.86 \pm 0.41^{\mathrm{a}}$ & $76.62 \pm 0.07^{\mathrm{c}}$ & $80.38 \pm 0.15^{\mathrm{b}}$ \\
Proteins $(\mathrm{g} / 100 \mathrm{~g} \mathrm{dw})$ & $10.65 \pm 0.47^{\mathrm{b}}$ & $16.0 \pm 0.05^{\mathrm{a}}$ & $8.08 \pm 0.14^{\mathrm{c}}$ \\
Fat $(\mathrm{g} / 100 \mathrm{~g} \mathrm{dw})$ & $2.23 \pm 0.02^{\mathrm{b}}$ & $1.14 \pm 0.01^{\mathrm{c}}$ & $4.22 \pm 0.03^{\mathrm{a}}$ \\
Energy $(\mathrm{kcal} / 100 \mathrm{~g} \mathrm{dw})$ & $390.09 \pm 1.32^{\mathrm{a}}$ & $380.74 \pm 0.17^{\mathrm{b}}$ & $391.83 \pm 0.04^{\mathrm{a}}$ \\
\hline Fructose & $0.71 \pm 0.33^{\mathrm{c}}$ & $2.04 \pm 0.14^{\mathrm{a}}$ & $0.95 \pm 0.20^{\mathrm{b}}$ \\
Glucose & $1.24 \pm 0.46$ & nd & nd \\
Mannitol & $3.14 \pm 1.18^{\mathrm{c}}$ & $5.16 \pm 0.21^{\mathrm{b}}$ & $6.20 \pm 0.25^{\mathrm{a}}$ \\
Trehalose & $9.29 \pm 0.51^{\mathrm{a}}$ & $8.41 \pm 0.24^{\mathrm{b}}$ & $4.62 \pm 0.02^{\mathrm{c}}$ \\
Total Sugars (g/100 g dw) & $14.38 \pm 2.47^{\mathrm{b}}$ & $15.61 \pm 0.59^{\mathrm{a}}$ & $11.77 \pm 0.03^{\mathrm{c}}$ \\
\hline C16:0 (palmitic) & $7.56 \pm 0.05^{\mathrm{c}}$ & $9.40 \pm 0.11^{\mathrm{b}}$ & $15.47 \pm 0.12^{\mathrm{a}}$ \\
C18:0 (stearic) & $1.93 \pm 0.08^{\mathrm{a}}$ & $1.51 \pm 0.05^{\mathrm{b}}$ & $1.96 \pm 0.15^{\mathrm{a}}$ \\
C18:1n9c (oleic) & $30.41 \pm 0.01^{\mathrm{b}}$ & $1.87 \pm 0.41^{\mathrm{c}}$ & $38.15 \pm 0.01^{\mathrm{a}}$ \\
C18:2n6c (linoleic) & $57.16 \pm 0.01^{\mathrm{b}}$ & $82.55 \pm 0.58^{\mathrm{a}}$ & $42.22 \pm 0.11^{\mathrm{c}}$ \\
C18:3n3 alfa linolenic) & $0.11 \pm 0.00^{\mathrm{c}}$ & $0.13 \pm 0.02^{\mathrm{a}}$ & $0.12 \pm 0.01^{\mathrm{b}}$ \\
\hline SFA (percent) & $10.59 \pm 0.04^{\mathrm{c}}$ & $14.12 \pm 0.06^{\mathrm{b}}$ & $18.52 \pm 0.10^{\mathrm{a}}$ \\
MUFA (percent) & $31.90 \pm 0.04^{\mathrm{b}}$ & $2.62 \pm 0.06^{\mathrm{b}}$ & $39.03 \pm 0.03^{\mathrm{a}}$ \\
PUFA (percent) & $57.51 \pm 0.00^{\mathrm{b}}$ & $83.26 \pm 0.52^{\mathrm{a}}$ & $42.46 \pm 0.01^{\mathrm{c}}$ \\
\hline
\end{tabular}

dw- dry weight; nd- not detected. Palmitic acid (C16:0); Stearic acid (C18:0); Oleic acid (C18:1n9c); Linoleic acid (C18:2n6c); $\alpha$-Linolenic acid (C18:3n3). SFA- saturated fatty acids; MUFA- monounsaturated fatty acids; PUFA- polyunsaturated fatty acids. The difference to $100 \%$ corresponds to other 18 less abundant fatty acids (data not shown). In each row, different letters mean significant differences between samples $(p<0.05)$. 
Table 2. Tocopherols, organic acids and phenolic compounds identified in Boletus edulis, Lentinus edodes and Xerocomus badius fruiting bodies from Poland.

\begin{tabular}{llll}
\hline Compound & Boletus edulis & Lentinus edodes & Xerocomus badius \\
\hline$\alpha$-tocopherol & $9.70 \pm 0.99^{\mathrm{b}}$ & $9.08 \pm 0.97^{\mathrm{b}}$ & $73.14 \pm 2.54^{\mathrm{a}}$ \\
$\beta$-tocopherol & $29.20 \pm 1.41^{\mathrm{b}}$ & $18.55 \pm 0.89^{\mathrm{c}}$ & $77.62 \pm 1.56^{\mathrm{a}}$ \\
$\gamma$-tocopherol & nd & nd & $65.47 \pm 2.40$ \\
Total tocopherols $(\mu \mathrm{g} / 100 \mathrm{~g} \mathrm{dw})$ & $38.90 \pm 2.40^{\mathrm{b}}$ & $27.63 \pm 0.08^{\mathrm{c}}$ & $216.22 \pm 6.49^{\mathrm{a}}$ \\
\hline Oxalic acid & $0.75 \pm 0.01^{\mathrm{a}}$ & $0.22 \pm 0.05^{\mathrm{c}}$ & $0.29 \pm 0.01^{\mathrm{b}}$ \\
Quinic acid & nd & $0.50 \pm 0.03$ & nd \\
Malic acid & nd & nd & $2.05 \pm 0.01$ \\
Citric acid & nd & nd & $2.11 \pm 0.08$ \\
Fumaric acid & $0.07 \pm 0.00^{\mathrm{b}}$ & $0.22 \pm 0.00^{\mathrm{a}}$ & $0.21 \pm 0.00^{\mathrm{a}}$ \\
Total organic acids $(\mathrm{g} / 100 \mathrm{~g} \mathrm{dw})$ & $0.82 \pm 0.01^{\mathrm{c}}$ & $0.94 \pm 0.02^{\mathrm{b}}$ & $4.66 \pm 0.05^{\mathrm{a}}$ \\
\hline Protocatechuic acid & $0.80 \pm 0.06^{\mathrm{b}}$ & $0.14 \pm 0.01^{\mathrm{c}}$ & $1.14 \pm 0.35^{\mathrm{a}}$ \\
$p$-Hydroxybenzoic acid & $0.76 \pm 0.06^{\mathrm{a}}$ & $0.19 \pm 0.01^{\mathrm{c}}$ & $0.30 \pm 0.03^{\mathrm{b}}$ \\
$p$-Coumaric acid & $0.33 \pm 0.02$ & $\mathrm{nd}$ & $\mathrm{nd}$ \\
Total phenolic compounds $(\mathrm{mg} / 100 \mathrm{~g} \mathrm{dw})$ & $1.89 \pm 0.02^{\mathrm{a}}$ & $0.33 \pm 0.00^{\mathrm{c}}$ & $1.44 \pm 0.32^{\mathrm{b}}$ \\
Cinnamic acid & $0.31 \pm 0.05^{\mathrm{a}}$ & $0.07 \pm 0.00^{\mathrm{c}}$ & $0.29 \pm 0.04^{\mathrm{b}}$ \\
\hline
\end{tabular}

dw- dry weight; nd- not detected. In each row, different letters mean significant differences between samples $(p<0.05)$. 
A)
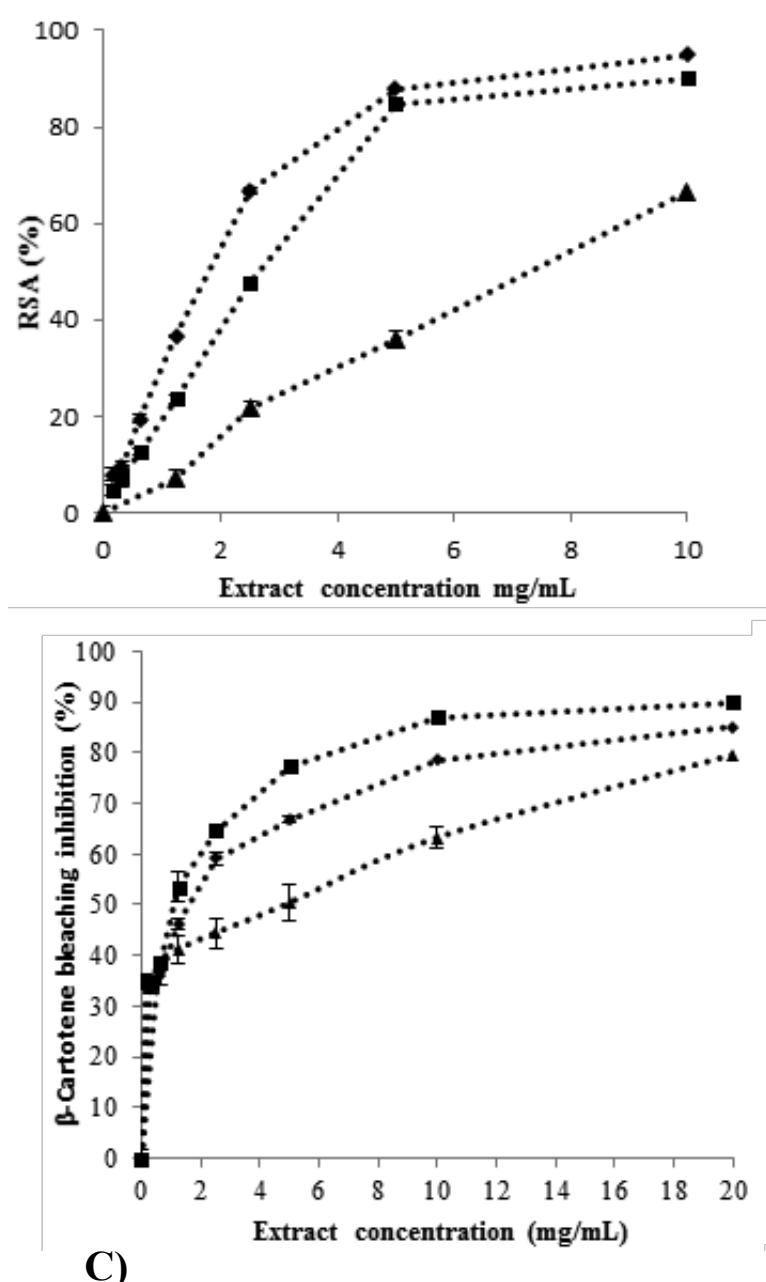

B)
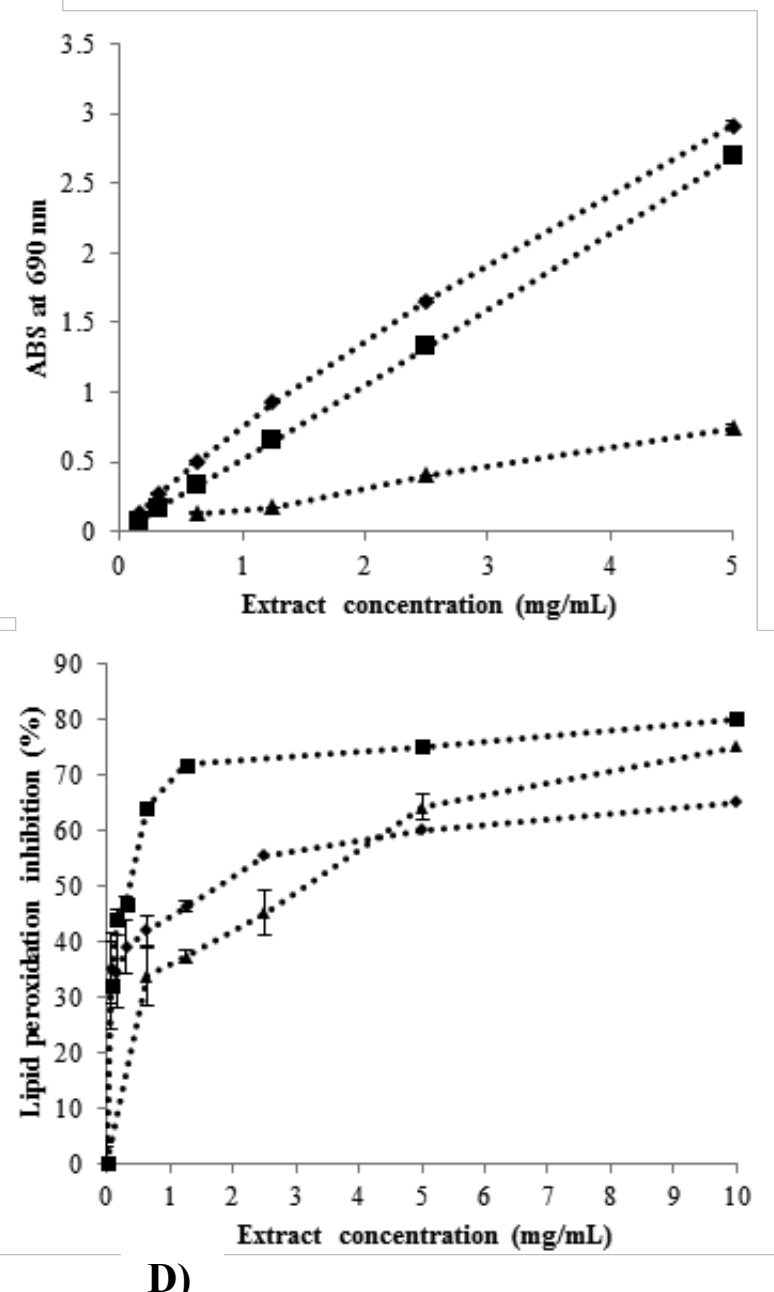

Figure 1. Antioxidant activity of Boletus edulis $(\cdot \bullet \cdot \cdots)$, Xerocomus badius $(\cdots \bullet \cdot \cdots)$ and Lentinus edodes ( $\cdots \mathbf{A} \cdot \cdot)$ : A) DPPH radical-scavenging activity $\left(\mathrm{EC}_{50}\right.$ values: B. edulis: $1.80 \pm 0.01 \mathrm{mg} / \mathrm{mL}$; X. badius: $2.65 \pm 0.06 \mathrm{mg} / \mathrm{mL}$; L. edodes: $7.30 \pm 0.13 \mathrm{mg} / \mathrm{mL}$ ); B) Reducing power $\left(\mathrm{EC}_{0.5}\right.$ values: B. edulis: $0.63 \pm 0.02 \mathrm{mg} / \mathrm{mL} ;$ X. badius: $0.96 \pm 0.01$ $\mathrm{mg} / \mathrm{mL}$; L. edodes: $3.19 \pm 0.03 \mathrm{mg} / \mathrm{mL})$; C) $\beta$-carotene bleaching inhibition $\left(\mathrm{EC}_{50}\right.$ values: B. edulis: $1.61 \pm 0.05 \mathrm{mg} / \mathrm{mL} ;$ X. badius: $1.10 \pm 0.05 \mathrm{mg} / \mathrm{mL}$; L. edodes: $3.54 \pm$ $0.55 \mathrm{mg} / \mathrm{mL}$ ); D) Lipid peroxidation inhibition ( $\mathrm{EC}_{50}$ values: B. edulis: $1.71 \pm 0.27$ $\mathrm{mg} / \mathrm{mL}$; X. badius: $0.37 \pm 0.02 \mathrm{mg} / \mathrm{mL}$; L. edodes: $33.16 \pm 0.17 \mathrm{mg} / \mathrm{mL})$. Each value is expressed as mean $\pm \operatorname{SE}(n=3)$. 


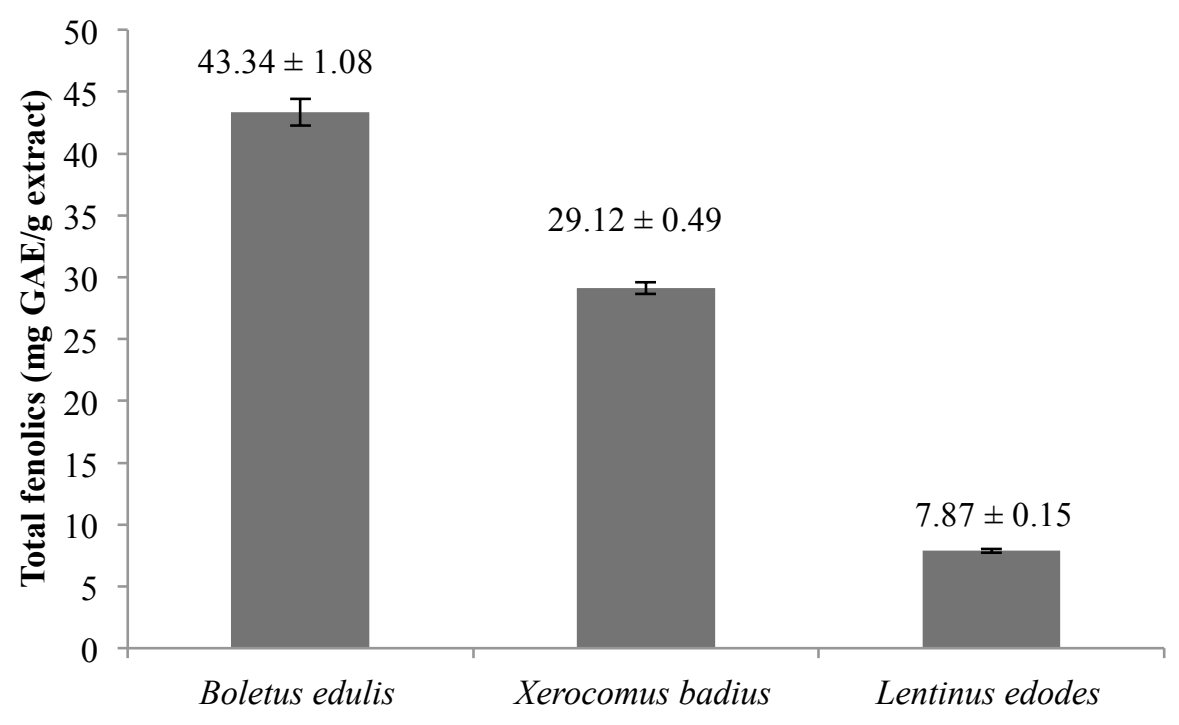

Figure 2. Total phenolic content by the Folin-Ciocalteu assay. Each value is expressed as mean $\pm \operatorname{SE}(n=3)$. 